
A C T A
I $\mathrm{CH}$

Fish physiology

\title{
DETERMINATION OF OXYGEN CONDITIONS IN REARING CARP (CYPRINUS CARPIO L.) LARVAE
}

\section{OKREŚLENIE WARUNKÓW TLENOWYCH W PODCHOWYWANIU WYLEGU KARPIA (CYPRINUS CARPIO L.)}

\author{
Inland Fisheries Institute, Olsztyn \\ Department of River Fishery at Zabieniec
}

Oxygen conditions were determined for rearing carp (Cyprinus carpio L.) larvae in $33.1 \pm 0.3^{\circ} \mathrm{C}$. They amounted to: 96.1 , 119.6 and $167.7 \%$ saturation of water with oxygen in optimal conditions 43.0 and $60.6 \%$ for the required conditions, and $23.1 \%$ for the critical conditions.

\section{INTRODUCTION}

Knowledge on the oxygen conditions is of primary importance for the intensification of fish production (Lavroskij et al. 1988). It is known that proper aeration of water in fish rearing may favourably affect their growth, survival, use of feeds, stocking densities as well as production safety and stability (Rümmler 1986). It is also known that even oversaturation of water with oxygen does not induce gas disease in fish (Colt 1986).

The aim of the experiment was to follow the effect of different levels of water saturation with oxygen on the rate of growth, condition and survival of carp larvae reared in high temperatures. 


\section{MATERIAL AND METHODS}

Three-day carp larvae originating from a hatchery were used in the experiment. They were a progeny of one female. Initial individual weight of the fish was $1.7 \pm 0.2 \mathrm{mg}$, average total length was $6.6 \pm 0.2 \mathrm{~mm}$. The larvae were stocked onto 7 identical flow-through plastic basins, $13 \mathrm{dm}^{3}$ in capacity. All basins were stocked at the same time with the same number of fish. Stocking rate amounted to 10 larvae per $1 \mathrm{dm}^{3}$ (130 fish per basin). Water temperature was gradually raised during 24 hours, from the initial temperature of $21.0^{\circ} \mathrm{C}$ to the final one of $33.0^{\circ} \mathrm{C}$. Water temperature was controlled automatically; it was maintained at the level of $33.1 \pm 0.3^{\circ} \mathrm{C}$. Water used in the experiment was pumped from a well and deironed. It was degassified with the vacuum method of Mount (1964) in order to protect the fish against gas disease, and then it was oxygenated directly in the fish basins with oxygen rotameters. Gaseous oxygen was used; it was obtained decompressing liquid oxygen. Constant ranges of saturation with oxygen were maintained in particular basins throughout the experiment. In order to disperse oxygen in water pumice stone cubes were used, of the type usually used in aquaria.

Oxygen content was determined with Winkler's method and the results were presented in per cents of saturation according to the table given by Mortimer (1981).

Fish were fed ad libitum several times daily with live zooplankton. The basins were illuminated 24 hours. Constant water flow (water exchange rate 20-25 times per $24 \mathrm{~h}$ ) and frequent cleaning of the basing practically excluded the possibility of sediment formation and prevented $\mathrm{CO}_{2}$ increase. Water $\mathrm{pH}$ was at the level 7.7-8.0.

Water outflows were covered with a net to prevent fish escape. All fish were fished out after 7 days of rearing and preserved in 3\% formalin. Individual weight and length of the fish were determined and so was Fulton's index of condition. In the latter case the following formula was used: $\mathrm{K}=(\mathrm{W}) / 1^{3} \times 100$, where $\mathrm{W}$ - fish weight, 1 - total fish length (Ricker 1968). Mean values and standard deviations were calculated for each sample.

Mean fish weights and Fulton's condition indices for the basins were compared using Duncan's test (1977). It allowed to quality final fish weights in particular basins into 5 groups differing statistically $(a, b, c, d, e)$. As regards the fish condition, two statistically different groups ( $\mathrm{f}, \mathrm{g}$ ) were distinguished.

Scheme of the experiment is presented in Fig. 1. 


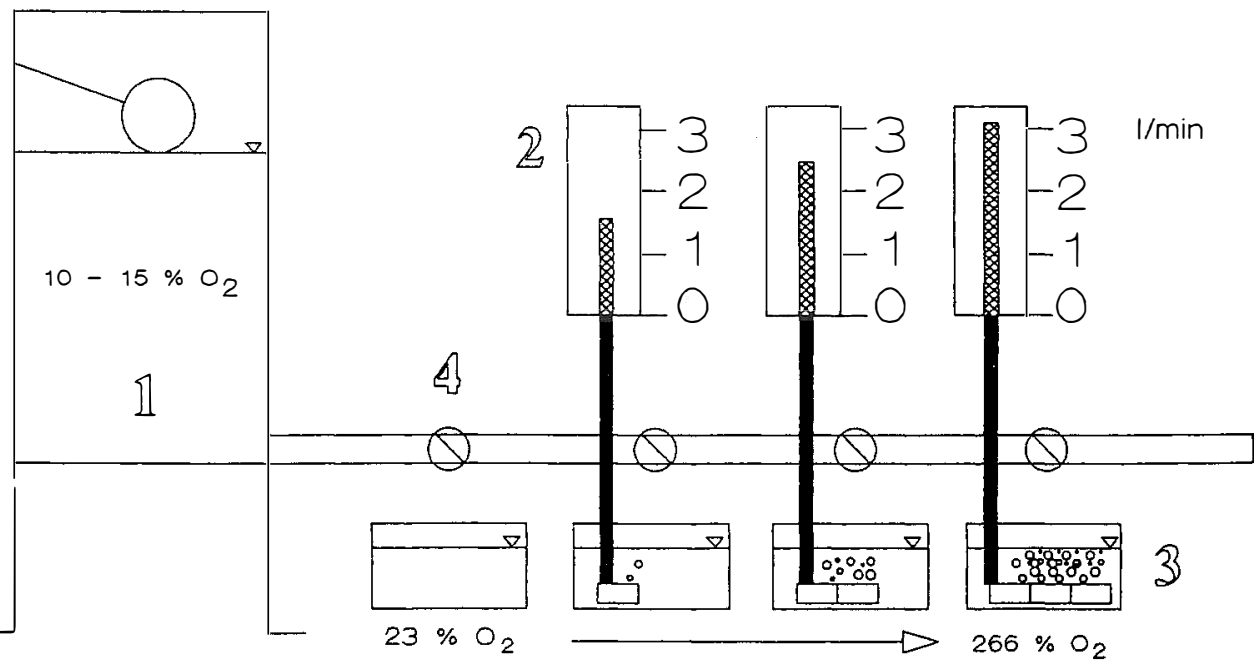

Fig. 1. Scheme of the experiment: 1. Tank with deoxidized water, 2. Oxygen rotameters, 3. Water oxygenating cubes, 4. Taps supplying the basins with water

\section{RESULTS}

The results of the experiment are presented in Table 1.

The most optimal conditions were obtained during rearing carp larvae in the basins no. 4,5 and 6 , in which water saturation with oxygen was respectively $96.1 \pm 21.4$, $119.6 \pm 21.2$ and $167.6 \pm 17.0 \%$.

Saturation of water with oxygen in the basins no. 2 and 3 was $43.9 \pm 6.0$ and $60.6 \pm 21.4 \%$, and those conditions were defined as required for carp larvae.

Decisively the worst results of rearing were observed in the basin no. 1, in which water saturation with oxygen was $23.1 \pm 4.3 \%$. Fish in this basin were characterized by very slow growth and low condition index. In course of rearing this fish did not eat up zooplankton doses and they tended to remain just under the water surface, suggesting that they were periodically forced to use atmospheric air. Oxygen conditions in this basin should be defined as critical.

In the basin no. 7, in which average supersaturation with oxygen was $226 \pm 16.0 \%$, mean fish weight was comparable to the one in the basins with optimal oxygen conditions. On the other hand, fish condition in this basin was comparable to that in the basin in which oxygen conditions were defined as critical.

Fish survival was high in all basins, from 88.5 to $93.1 \%$. 
Rearing of carp larvae in different oxygen conditions.

Duration of rearing: 7 days. Water temperature $33.1 \pm 0.3^{\circ} \mathrm{C}$

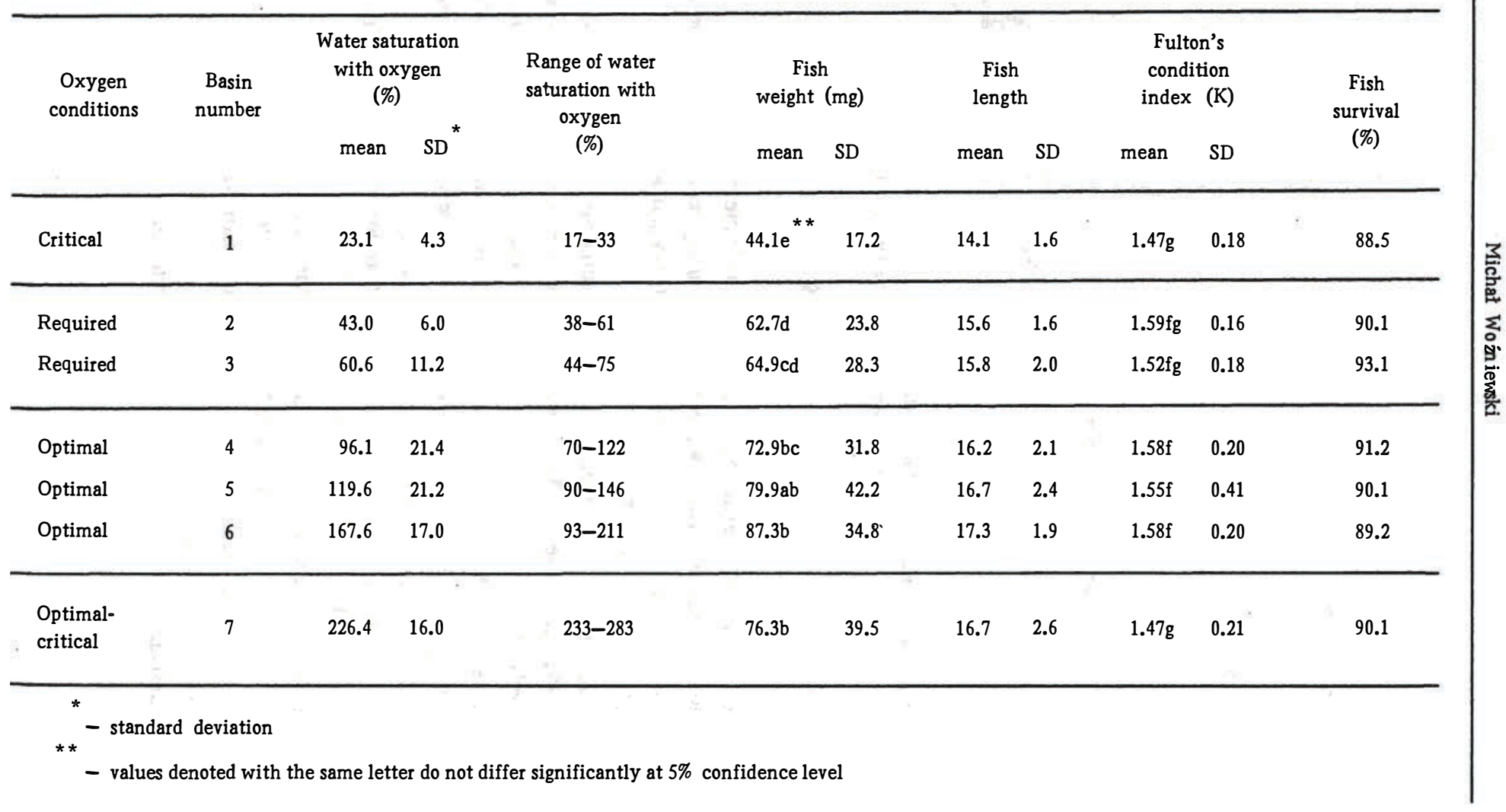




\section{DISCUSSION}

Oxygenation of water is an abiotic factor of decisive importance in the intensification of rearing carp larvae as well as larvae of other fish (Rümmler 1986). Until recently it was generally accepted that oversaturation with oxygen enhanced gas disease (Weitkamp and Katz 1980). It is knowh that the symptoms of gas disease may appear in fish during water heating and intensive mixing, and also during water punping as a result of to great differences between pressure of gas dissolved in water and local atmospheric pressure (Colt 1986). In order to prevent this, water used in the experiment was degassified using the vacuum method of Mount (1964) to remove the main cause of the disease i.e. nitrogen. No disease symptoms were observed. Some fish losses which occurred during the experiment could be ascribed to predatory Copepoda which were present in live zooplankton used to feed the fish.

Water temperature maintained in course of the experiment was defined by Korneev (1982) and Lirski (1984) as optimal when high-protein food is used to feed the fish.

Saturation of water with oxygen in the basin no. 4, 5 and 6, in which optimal growth rate was observed, was close to the data presented by Rümmler (1986). According to this author optimum of fish growth occurred at $90-120 \%$ saturation. On the other hand, Bajkalova (1983) found that average weight of carp reared in $26-27^{\circ} \mathrm{C}$ in water with $25 \%$ saturation with oxygen was about $17 \%$ higher than in the control group (110\% saturation). My own studies suggest that $266.4 \%$ saturation (basin no. 7) had no adverse effect on average fish weight, although it decreased Fulton's index of fish condition. It may be assumed that this was caused by to intensive turbulence of water, so that the fish were not able to move freely. Rümmler (1986) stated that in the case of using oxidates for intensive water saturation with oxygen it was possible to attain a few hundred per cent saturation at a very low cost. It can be concluded from the paper by Golidov and Popova (1978) that oversaturation with oxygen of even a few hundred per cent (more than $40 \mathrm{mg} \mathrm{O} / \mathrm{dcm}^{3}$ ) did not limit development of carp larvae. Similar conclusions were presented by Ostroumova (1969) who studied rate of growth of rainbow trout larvae in highly oversaturated water (about 300\% saturation). Chiba (1966) and Klajstorin (1982) qualified water saturation with oxygen of 43.0 and $60.6 \%$ i.e. as that attained in the basins no. 2 and 3 as required conditions for normal commercial carp breeding.

Unsatisfactory oxygen conditions were observed in the basin no. 1, in which water saturation with oxygen was $23.1 \%$ on the average. These conditions were defined as critical. They resulted decreased food uptake by the fish, breathing difficulties, noticeable inhibition of growth rate. Satisfactory fish survial $(88.5 \%)$ in these condition was due to the fact that cyprinid fishes are more able to use atmospheric air for breathing than other fish such as salmonids (Kraiem and Pattée 1980). Alekseenko (1981) observed growth rate of grass carp larvae in $30^{\circ} \mathrm{C}$ at $22-32 \%$ saturation with 
oxygen and found that insufficient oxygen levels inhibited fish growth. The results obtained by this author correspond to critical oxygen conditions for carp larvae.

\section{CONCLUSIONS}

Levels of water saturation with oxygen in the case of rearing carp larvae in constant temperature $33.1 \pm 0.3^{\circ} \mathrm{C}$ amounted to: optimal one - over $96 \%$, up to $168 \%$ (for the range $70-211 \%$ ), the lowest required one - over $43 \%$ (for the range $38-75 \%$ ), critical one $-23 \%$ (for the range $17-33 \%$ ).

Higher saturation with oxygen, 266\% on the average (range 233-283\%) lowered fish condition, although growth rate of the biomass remained optimal. The effects of fish rearing in these conditions might have benn caused by mechanical factor, i.e. increased water current in the experimental basins.

\section{REFERENCES}

Alekseenko V.R., 1981: Vyzivaemost i rost licinok rastitelnojadnych ryb v zavisimosti ot koncentracii kisloroda v vode. Gidrobiol. Z. 17, 3:12, 9-130. (in Russian).

Bajkalova N.D., 1983: Vlijanie povysennoj koncentracii kisloroda v vode na rost licinok karpa. Sb. Nauc. Tr. GOSNIORCh. 206: 78-83. (in Russian).

Chiba K., 1966: A study on the influence of oxygen concentracion on the growth of juvenile cammon carp. Bull. Freshwat. Fish. Res. Lab. 15, 1: 35-47.

Colt J., 1986: Gas supersaturation - impact on the desing and operation of aquatic system. Aquacultural Engineering, 5: 49-85.

Dangschat H., M. Lukowicz, Ch. Proske, 1980: Intensive Fischhaltung - Moglichkeiter und Problem der modernen Aquakultur. KTBL, Arbeitsemeinschaft, Darmstadt: 1-56.

Gulidor M.V., K.S. Popora, 1978: Vlijanie porysennych koncentracji kisloroda na chod vyluplenija i morfologiceskije osobennosti zorodysej nekotorych karpovych ryb. W: Ekolo-morfologiceskie i ekologo-fizjologiceskie issledovanija razvitija ryb. Moskva: 136-148. (in Russian).

Ivacha V., J. Limanskij, Z. Makina, 1972: Opyt vyrascivanija segoletkov karpa v setcatych sadkach $\mathrm{v}$ vodijeme-ochladitele Emievkoj GRES. Rybovod. rybolov: 5-6. (in Russian).

Kljastorin L.B., 1982: Vodnoe dychanie i kislorodnye potrebnosti ryb. Moskva: 1-168. (in Russian).

Korneev A.N., 1982: Razvedenie karpa i drugich vidov ryb na teplich vodach. Moskva: 1-150. (in Russian).

Kraiem M., E. Pattée, 1980: La tolérance à la température et au déficit en oxygène chez le Barbeau (Barbus barbus L.) et d'autres espèces provenant des zones piscicoles voisines. Arch. Hydrobiol. 88, 2: 250-261.

Lavrovskij V.V., J.I., Esarskin, V.P. Panov, N.N. Kapalinn, 1988: Perspektivy oksygenacji vody v industralnom rybovodstvie. Ryb. choz. 7: 56-59. (in Russian).

Lirski A., 1984: Podchów wylęgu ryb karpiowatych w wodzie o wysokiej temperaturze. [Rearing carp larvae in water at high temperature]. Gosp. rybna, 8: 10-12. (in Polish).

Mortimer C.H., 1981: The oxygen content of air - saturated fresh water over ranges of temperature and atmospheric pressure of limnological interest. Mitt. Internat. Verein. Limnol. 22: 1-23.

Mount D.J., 1964: Additional information on a system for controlling the dissolved oxygen content of water. Trans. Amer. Fish. Soc. 93, 1: 100-103. 
Ostroumova J.N., 1969: Rost i razvitje embrionov raduznoj foreli pri raznoj koncentracji kisloroda v vode. Izv. GOSNIORCh., 68,: 202-222. (in Russian).

Ostroumova J.N., 1978: Rol sbalansirovannosti korma pri vyrascivanii karpa na teplych vodach. Ryb. choz. 12: 24-26. (in Russian).

Platt G., 1977: Problemy rachunku prawdopodobieństwa i statystyki matematycznej. [Problems of probability and statistics]. PWN: 1-377.

Ricker W.E., 1968: Methods for assesment of fish production in fresh water. Blackwell Scientific Publications, Oxford, Edinburgh: 1-313.

Rümmler F., 1986: Havariesicherung unter Einbeziehung moderner Automatisierungstechnik und Moglichkeiten des Einsatzes der Sauerstofhegasung. Z. Binnenfisch. DDR, Berlin, 33, 10: 293-297.

Weitkamp D.E., M. Katz, 1980: A review of disselved gas supersaturation literature. Trans. Am. Fish. Soc. 109, 6: 659-702.

Translated by: Dr hab. M. Bnińska

Michał WOŹNIEWSKI

OKREŚLENIE WARUNKÓW TLENOWYCH W PODCHOWYWANIU WYLĘGU KARPIA

(CYPRINUS CARPIO L.)

\section{STRESZCZENIE}

Przedstawiono wyniki badań dotyczące próby określenia warunków tlenowych w podchowaniu wylęgu karpia (Cyprinus carpio L.). Do doświadczeń użyto jednorodnego 3-dniowego wylęgu karpia o średniej masie $1,7 \pm 0,2 \mathrm{mg}$ i długości całkowitej 6,6 $\pm 0,2 \mathrm{~mm}$, którym obsadzono 7 basenów przepływowych. Obsada każdego $z$ basenów była taka sama i wynosiła 10 sztuk ryb na $1 \mathrm{dcm}^{3}$ wody. Temperaturę wody utrzymywano na stałym poziomie $33,1 \pm 0,3^{\circ} \mathrm{C}$. Nasycenie wody tlenem w poszczególnych basenach było różne $\mathrm{i}$ wynosiło od 23,1 do 266,4\%. Ryby karmiono zooplanktonem "ad libitum". Doświadczenie trwało 7 dni (rys. 1).

Końcowe średnie masy ryb oraz współczynniki kondycji Fultona z poszczególnych basenów porównano testem statycznym Duncana. Na tej podstawie określono optimum wzrostu ryb $z$ basenów, gdzie nasycenie wody tlenem wnosiło $96,1 \pm 21,4,119,6 \pm 21,1$ i $167,6 \pm 17,0 \%$. Określono również zakres wymaganych nasyceń wody tlenem wynoszący $42,0 \pm 6,0 \%$ i $61,6 \pm 11,2 \%$ oraz poziomów krytycznych $23,1 \pm 4,3 \%$.

Stosowanie wysokich nasyceń wody tlenem na poziomie $266,4 \pm 16,0 \%$ zapewniło dobre tempo wzrostu, ale wpłynęło na obniżenie współczynnika kondycji podchowywanego wylęgu karpia.

Author's address:

Received: 1993.05.05

Dr Michał Woźniewski

Instytut Rybactwa Śródlądowego

Zakład Rybactwa Rzecznego

Żabieniec

05-500 Piaseczno

Polska (Poland) 